\title{
Pengukuran Kinerja Perusahaan dengan Menggunakan Integrated Performance Measurement Systems
}

\author{
Muhammad Nur* dan Denilah Yani \\ Jurusan Teknik Industri, Fakultas Sains dan Teknologi, Universitas Islam Negeri Sultan Syarif Kasim, Riau, Indonesia \\ ${ }^{*}$ Corresponding Author:muhammad.nur@uin-suska.ac.id
}

\begin{abstract}
Abstrak - PT. Sejahtera Panca Jaya adalah perusahaan yang bergerak dalam bidang vulkanisir ban. Perkembangan industri vulkanisir ban memunculkan persaingan yang cukup ketat diantara vulkanisir ban khususnya di Pekanbaru. Selama ini perusahaan mengalami kesulitan dalam mencapai target produksi, kesulitan yang dialami perusahaan disebabkan oleh proses produksi yang dilakukan tidak sebanding dengan pendapatan yang diperoleh serta buruknya pengelolaan manajemen keuangan perusahaan. Selama ini perusahaan belum pernah melakukan pengukuran kinerja secara terintegrasi. Pengukuran kinerja sangat penting bagi perusahaan, dapat membantu perusahaan untuk mengetahui tingkat performansi kerja yang baik. Untuk era sekarang, cara terbaik untuk mengukur kinerja adalah dengan memppertimbangkan stakeholder perusahaan dan mengidentifikasi kebutuhan stakeholder. Penelitian ini bertujuan untuk mengetahui kebutuhan stakeholder, memberikan usulan dan meningkatkan kinerja perusahaan dengan menerapkan metode IPMS yang dikombinasikan dengan AHP. Hasil dari pengukuran kinerja diperoleh sebanyak $16 \mathrm{KPI}$ yang telah teridentifikasi, terdapat $4 \mathrm{KPI}$ yang diambil dari setiap stakeholder dengan nilai bobot tertinggi. KPI dengan nilai bobot tertinggi akan diberikan usulan perbaikan. Dengan dilakukan perbaikan terhadap indikator diharapkan dapat meningkatkan kinerja perusahaan kedepannya.
\end{abstract}

Kata Kunci: AHP, IPMS, KPI ,Pengukuran Kinerja

\section{Pendahuluan}

Persaingan adalah suatu hal yang tidak dapat dihindari. Setiap perusahaan dituntut untuk berbenah dalam setiap aspek-aspek kinerja perusahaannya, sehingga perusahaan dapat tetap bersaing dengan perusahaan lain. Pada saat ini, perusahaan dihadapkan pada kompleksitas dan turbulensi dalam lingkungan bisnisnya, dengan lingkungan yang demikian menuntut suatu manajemen yang fleksibel dan dinamis dalam menghadapi setiap perubahan yang terjadi. Untuk dapat tetap eksis dalam dunia bisnis dengan persaingan yang begitu keras, perusahaan harus dapat mengikuti perkembangan yang ada dengan sebaik-baiknya, baik dari segi internal perusahaan, maupun dari segi eksternal. Media untuk hal tersebut adalah dengan mengetahui tingkat perfomasi perusahaan dengan melakukan pengukuran kinerja[3].

Dalam pengukuran kinerja perusahaan diperlukan metode yang bisa mengukur kinerja seluruh organisasi perusahaan tersebut. Karena pengukuran kinerja tidak hanya mementingkan pada keuntungan jangka pendek perusahaan tetapi juga dalam jangka panjang. Pengukuran kinerja gunanya untuk mengetahui tingkat kemampuan perusahaan, apakah perusahaan tersebut telah berjalan dengan baik, atau justru mengalami kemerosotan [5].

PT. sejahtera panca jaya pekanbaru merupakan perusahaan yang bergerak dalam pembuatan vulkanisisr adalah sebuah tatakan yang terbuat dari ban yang berguna untuk diolah kembali. Perusahaan ini berdiri pada tahun 2014 dengan jumlah karyawan 16 orang. Selama ini perusahaan belum pernah melakukan pengukuran kinerja secara terintegritas, sehingga dibutuhkannya pengukuran kinerja yang memfokuskan kepada seluruh stakeholder yang terkait dengan perusahaan.

PT. sejahtera panca jaya pekanbaru melakukan proses produksi setiap hari untuk memenuhi targetnya, 
tetapi perusahaan belum bisa memenuhi target produksi sesuai permintaan pelanggan.

Selama ini perusahaan mengalami kesulitan dalam mencapai target produksi, kesulitan yang dialami perusahaan disebabkan oleh proses produksi yang dilakukan tidak sebanding dengan pendapatan yang diperoleh serta buruknya pengelolaan manjemen keuangan perusahaan.

Maka dari itu dibutuhkan model yang mampu menggambarkan kinerja keseluruhan perusahaan seperti metode Integrated Performance Measurement System dan Analytical Hierarchy Process. Metode Performance Measurement System merupakan metode pengukuran kinerja yang terintegrasi yaitu menggukur kinerja suatu perusahaan yang dilakukan secara topdown dengan memperhatikan kebutuhan dari setiap stakeholder-nya dan tetap memonitor posisi perusahaan terhadap pesaingnya. Sedangkan metode Analytical Hierarchy Process merupakan model pendukung keputusan yang menguraikan masalah multi faktor atau multi kriteria yang komplek menjadi hirarki. Tujuan dari model IPMS, agar sistem pengukuran kinerja lebih akurat, terintegrasi, efektif dan efisien. Berbeda dengan model lainnya, IPMS menjadikan keinginan stakeholder menjadi titik awal dalam melakukan perancangan sistem pengukuran kinerjanya. Peranan stakeholder tidak hanya pemegang saham, melainkan beberapa pihak yang memiliki kepentingan atau dipentingkan oleh perusahaan seperti konsumen, karyawan, pemasok dan lain-lain [2].

\section{Tinjauan Pustaka}

\section{Pengertian Kinerja Perusahaan}

Kinerja perusahaan adalah suatu tampilan keadaan secara utuh atas perusahaan selama periode waktu tertentu, merupakan hasil atau prestasi yang dipengaruhi oleh kegiatan operasional perusahaan dalam memanfaatkan sumber daya - sumber daya yang dimiliki. Kinerja perusahaan adalah ukuran tingkat keberhasilan manajemen dalam mengelola sumberdaya keuangan perusahaan, terutama pada pengelolaan investasi sebagai upaya untuk menciptakan nilai bagi pemegang saham. Artinya, kinerja perusahaan merupakan indikator tingkatan prestasi yang dicapai dan mencerminkan keberhasilan manajer atau pengusaha ${ }^{[2]}$.

\section{Key Performance Indicators (KPI)}

KPI (Key Performance Indicators) atau indikator kinerja kunci dalam bahasa Indonesia, adalah matriks finansial ataupun non-finansial yang digunakan untuk membantu suatu organisasi menentukan dan mengukur kemajuan terhadap sasaran organisasi. Pada organisasi bisnis, KPI digunakan dalam intelijen bisnis untuk menilai keadaan saat ini suatu bisnis dan menentukan suatu kebijakan tindakan terhadap keadaan tersebut. KPI pada umumnya digunakan untuk menilai aktivitas- aktivitas yang sulit diukur seperti keuntungan pengembangan, kepemimpinan, perjanjian, layanan dan kepuasan. KPI umumnya dikaitkan dengan strategi organisasi. Komponen KPI akan berbeda tergantung sifat dan strategi organisasi. KPI merupakan bagian dari kunci suatu sasaran terukur yang terdiri dari arahan, indikator kinerja, tolak ukur, target dan kerangka waktu [1].

Key Performance Indicators (KPI) dapat diartikan sebagai indikator yang akan memberikan informasi sejauh mana kita telah berhasil mewujudkan sasaran strategis yang telah kita tetapkan. Dalam menyusun KPI baiknya harus menetapkan indikator kinerja yang jelas, spesifik dan terukur[9] Penilaian kinerja berdasarkan KPI bertujuan untuk:

1. Mengukur kesehatan dan kesejahteraan organisasi secara keseluruhan

2. Memfokuskan pada aspek atau area dari suatu kinerja oraganisasi yang kritikal dan vital secara berkelanjutan dan mengacu pada kesuksesan di masa yang akan datang.

3. Mengukur suatu kesuksesan dalam area yang dianggap penting dan proses yang mempengaruhi customer, pekerja, shareholder dan stakeholder.

4. Membangun total organisasi, individu departemen dan individual team sangat penting bagi perusahaan atau organisasi untuk paling tidak mengidentifikasi KPI nya.

\section{Pengertian Integrated Performance Measurement Syistem (IPMS)}

Integrated Performance Measurement Syistem (IPMS) merupakan metode pengukuran kinerja yang terintegrasi yaitu mengukur kinerja suatu perusahaan yang dilakukan secara top-down dengan memperhatikan kebutuhan dari setiap stakeholdernya dan tetap memonitor posisi perusahaan terhadap pesaingnya. IPMS merupakan sistem pengukuran kinerja yang dibuat di Centre for Statistic Manufacturing University of Stratchlcle, Glasgow. Tujuannya yaitu untuk mendeskripsikan bentuk pengukuran kinerja dalam arti yang tepat, untegrasi, efektif dan efisien. Untuk mencapai tujuan tersebut, secara garis besar dideskripsikan menjadi dua (2) kegiatan utama, yakni:

1. Pendeskripsian komponen pokok dari sistem pengukuran kinerja

2. Membuat garis arahan pengukuran kinerja terbaik yang sebaiknya digunakan.

Sebagai salah satu metode yang digunakan dalam pengukuran kinerja, IPMS memiliki ciri-ciri sebaga berikut $^{[16\}}$ :

1. Menyusun seluruh tugas dan aktivitas perusahaan sesuai dengan tujuan kritis level atas.

2. Memberikan kendali bisnis pada semua bagian dalam perusahaan, searah dengan strategi bisnis yang dimiliki. 
3. Melakukan program perbaikan yang searah dengan strategi bisnis perusahaan.

Model IPMS membagi level bisnis suatu oragnisasi menjadi empat (4) level, yaitu bisnis induk, Unit bisnis, Proses bisnis dan aktivitas bisnis. Sehingga perancangan sistem penilaian kinerja dengan model IPMS harus mengikuti tahapan - tahapan Performance Measurement Systems:

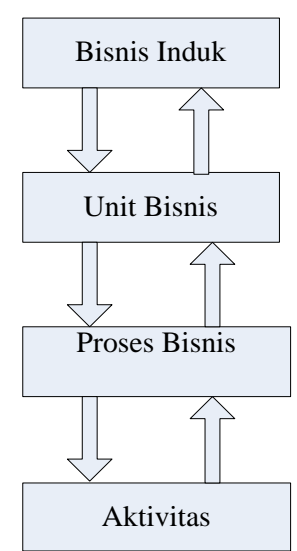

Gambar 1. Pembagian Level Organisasi

Level bisnis menjabarkan seluruh bisnis perusahaan dengan beberapa unit bisnis yang ada di dalamnya. Unit bisnis adalah bagian dariperusahaan yang memiliki fungsi dan proses bisnis tertentu yang bertujuan untuk melayani sebagian segmen pasar sesuai dengan tuntutan pasar yang semakin ketat.

Perancangan sistem penilaian kinerja dengan model IPMS harus mengikuuti tahapan-tahapan sebagai berikut: Identifikasi stakeholder dan requirement, melakukan External Monitor (Benchmarking), menetapkan Objective bisnis, mendefinisikan measure atau Key Performance Indicators (KPI), melakukan validasi KPI dan spesifikasi KPI.

\section{Metodelogi Penelitian}

Langkah-langkah yang ditempuh pada penelitian ini ditunjukkan oleh diagram alur penelitian berikut:

1. Observasi

Observasi merupakan pengumpulan data lansung terhadap obyek penelitian dengan tujuan untuk memahami kinerja dari perusahaan. Observasi dilakukan untuk mendapatkan informasi mengenai stakeholder perusahaan dan kebutuhan dan keinginan stakeholder perusahaan.

2. Wawancara

Wawancara dilakukan kepada pihak-pihak yang mengerti dan terlibat pada perusahaan. Hal ini dilakukan untuk mengetahui kinerja serta kondisi perusahaan secara menyeluruh dan aktivitas yang dilakukan perusahaan.

\section{Penyebaran kuesioner}

Kuesioner berisikan daftar pernyataan yang ditujukan kepada seluruh stakeholder terkait dengan topik penelitian yang telah ditetapkan. Dalam penelitian ini terdapat 3 kuesioner yang akan disebarkan yaitu Kuesioner pertama disusun dengan tujuan untuk mendapatkan indikator-indikator kebutuhan dari para stakeholder, penyebaran kuesioner 2 bertujuan untuk mengetahui posisi perusahaan terhadap pesaingnya, dan kuesioner ke3 yang berisikan indikator kinerja yang diperoleh dari kuesioner 1 dan 2 yang menggunakan metode AHP yang bertujuan untuk mengetahui tingkat kepentingan dari perusahaan.

4. Penentuan stakeholder Perusahaan

Pada tahap ini stakeholder sebagai pihak - pihak penting yang berhubunga baik secara langsung maupun tidak langsung dengan perusahaan, sehingga dapat menggerakkan jaminan keberadaan suatu perusahaan. Stakeholer yang terlibat dala penelitian ini meliputi pimpinan, pelanggan, karyawan dan supplier. ke 2 yaitu dimensi pengukuran seluruh stakeholder yang terlibat pada perusahaan seperti pemilik, karyawan, pemasok dan pelanggan.

5. Identifikasi Stakeholder Requirements

Pada tahap ini bertujuan untuk menggali kebutuhan dari masing-masing stakeholder yang telah ditetapkan sebelumnya. Untuk mengetahui stakeholder requirement dapat dilakukan dengan melakukan diskusi atau wawancara terhadap pihak perusahaan.

6. Identifikasi Eksternal Monitor

Pada tahap ini bertujuan untuk mengetahui posisi PT. Sejahtera Panca Jaya terhadap perusahaan pesaing sejenisnya, sehingga dapat mengetahui kekurangan dan kelebihan perkembangan kebutuhan bisnisnya.

7. Identifikasi Objectives Bisnis

Pada tahap ini dilakukan berdasarkan stakeholder requirement yang memiliki kemiripan, sehingga dapat digolongkan. Stakeholder requirement yanglah ditentukan sebelumnya akan dikelompokkan menjadi beberapa objectives yang lebih spesifik untuk meningkatkan kinerja perusahaan. Penggolongan objectives ini dilakukan dengan diskusi atau wawancara terhadap pihak perusahaan.

8. Penentuan Key Performance Indicator (KPI)

Pada tahap ini dilakukan sebagai ukuran untuk mengetahui tingkat pencapaian masing-masing objectives berdasarkan masing-masing requirement yang telah diidentifikasi sebelumnya.

9. Penyusunan Hierarki Kinerja

Penyusunan hierarki dilakukan berdasarkan KPI yang telah terbentuk dari stakeholder dan indikatornya masing-masing. 
10. Validasi dan Spesifikasi KPI

Proses validasi dilakukan dengan memberikan daftar KPI berupa kuesioner terhadap pihak perusahaan. Proses spesifikasi KPI dilakukan untuk mengetahui deskripsi jelas tentang KPI yang terdiri dari tujuan, keterkaitan dengan objectives, target perusahaan, cara mengukur KPI, frekuensi pengukuran dan sumber data.

11. Pembobotan KPI Pada tahap ini dilakukan berdasarkan penyusunan hierarki kinerja perusahaan dengan metode AHP

\section{Hasil dan Pembahasan}

\section{Mengidentifikasi Level Bisnis Perusahaan}

Perancangan sistem pengukuran kinerja dengan metode Integrated Performance Measurement Systems (IPMS), perlu dilakukan identifikasi level bisnis perusahaan yang terdiri dari level bisnis, level unit bisnis, level proses bisnis dan level aktivitas. Berikut adalah pembagian level pada PT. Sejahtera Panca Jaya Pekanbaru:

a. Bisnis Induk

Level bisnis induk untuk pengukuran kinerja adalah PT. Sejahtera Panca Jaya Pekanbaru

b. Unit Bisnis

Level unit bisnis untuk pengukuran kinerja adalah seluruh departemen yang terdapat pada PT. Sejahtera Panca Jaya. Departemen tersebut terdiri dari departemen pemeriksaan, filling, enveloping dan finishing.

c. Proses Bisnis

Level proses bisnis untuk pengukuran kinerja PT. sejahtera Panca Jaya Pekanbaru adalah pimpinan, karyawan, pelanggan dan supplier.

d. Aktivitas

Level aktivitas untuk pengukuran kinerja adalah seluruh aktivitas -aktivitas yang berkaitan langsung dengan PT. Sejahtera Panca Jaya Pekanbaru. pembagian level organisasi pada PT. Sejahtera Panca Jaya dapat dilihat padaa Gambar 2.

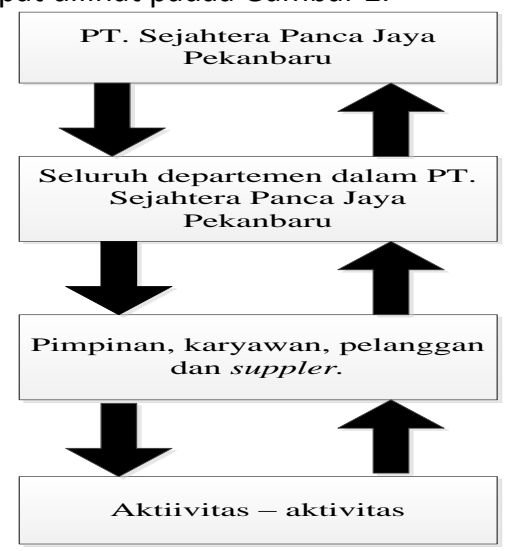

Gambar 2. Pembagian level organisasi

Mengidentifikasi kebutuhan stakeholder perusahaan ini dilakukan dengan wawancara, wawancara dilakukan secara terbuuka untuk memnuhi kebutuhan dari setiap
Stakeholder perusahaan dengan menggunakan prinsip IPMS. Stakeholder sendiri merupakan suatu aspek terpenting dalam keberhasilan suatu perusahaan.

Stakeholder dari PT. Sejahtera Panca Jaya adalah sebagai berikut:

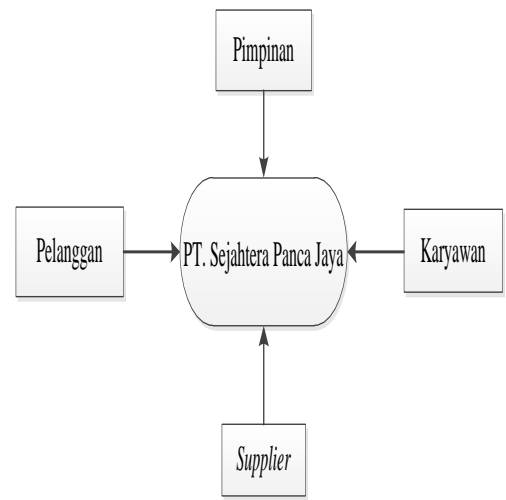

Gambar 3. Stakeholder

Adapun stakeholder yang telah ditetapkan adalah sebagai berikut:

1. Stakeholder Pelanggan

Pelanggan adalah stakeholder penting bagi perusahaan, dikarenakan pelanggan adalah raja bagi perusahaan yang harus senantiasa dipenuhi keinginan dan kebutuhannya untuk menjaga keberlangsungan hidup perusahaan sendiri. Pelanggan dari PT. Sejahtera Panca Jaya Pekanbaru adalah Salam Banindo, Sejahtera Ban, PT. Awal Bross, PT. Sinar Riau Abadi, PT. Riau Muda Jasa Sarana dan PT. Perintis.

\section{Stakeholder Karyawan}

Karyawan merupakan stakeholder penting kedua bagi perusahaan. Pemenuhan terhadap keinginan dan kebutuhan karyawan oleh perusahaan dapat menimbulkannya kepuasan bagi karyawan sendiri. Jumlah karyawan yang bekerja di PT. Sejahtera Panca Jaya Pekanbaru adalah 15 orang yang terbagi lagi dalam masing-masing bagian.

\section{Stakeholder Supllier}

Supllier sebagai salah satu Stakeholder yang mempunyai peranan penting dalam menentukan kelancaran apakah kegiatan operasional perusahaan dapat berjalan dengan lancar atau tidak. PT. Sejahtera Panca Jaya Pekanbaru melakukan kerja sama dengan beberapa pemasok guna pendukung berjalannya operasional perusahaan, yang terdiri dari New Techindo, Sukses Bersama Karunia Kasih, Timur Jaya dan Sumatera Kartndo.

4. Stakeholder Pimpinan Perusahaan

Pimpinan perusahaan merupakan Stakeholder yang sangat penting bagi perusahaan. Pimpinan akan bertanggung jawab atas keberlangsungan hidup dari perusahaan. Pemilik saham usaha PT. Sejahtera Panca Jaya Pekanbaru adalah Bapak Yanto Leonardi.

Dari masing-masing Stakeholder yang telah dijelaskan, maka dapat dilakukan pengidentifikasian 
kebutuhan Stakeholder. Identifikasi kebutuhan Stakeholder dapat diilakukan dengan wawancara terhadap pihak perusahaan yang mengetahui kondisi PT. Sejahtera Panca Jaya Pekanbaru. Berikut daftar Stakeholder requirement perusahaan:

\begin{tabular}{|c|c|}
\hline Stakeholder & Requirement (Kebutuhan) \\
\hline \multirow[t]{5}{*}{ Pelanggan } & $\begin{array}{l}\text { 1. Mutu dan Kualitas ban hasil } \\
\text { vulkanisir sesuai dengan standar }\end{array}$ \\
\hline & $\begin{array}{l}\text { 2. Pelayanan yang memuaskan } \\
\text { terhadap pelanggan }\end{array}$ \\
\hline & $\begin{array}{l}\text { 3. Pengiriman ban tepat waktu } \\
\text { sesuai dengan perjanjian }\end{array}$ \\
\hline & 4. Adanya kemudahan bertransaksi \\
\hline & $\begin{array}{lcc}\text { 5. Cepat tanggap } & \text { terhadap } \\
\text { complain pelanggan } & \\
\end{array}$ \\
\hline \multirow{7}{*}{ Karyawan } & $\begin{array}{l}\text { 1. Adanya jaminan keselamatan } \\
\text { kerja karyawan }\end{array}$ \\
\hline & $\begin{array}{l}\text { 2. Cepat tanggap terhadap keluhan } \\
\text { karyawan }\end{array}$ \\
\hline & $\begin{array}{l}\text { 3. Akomodasi karyawan yang } \\
\text { memadai }\end{array}$ \\
\hline & $\begin{array}{l}\text { 4. Peningkatan } \\
\text { karyawan }\end{array}$ \\
\hline & $\begin{array}{l}\text { 5. Adanya bonus dan reward bila } \\
\text { target produksi tercapai }\end{array}$ \\
\hline & $\begin{array}{l}\text { 6. Tingkat kesehatan dan } \\
\text { keselamatan yang terjamin }\end{array}$ \\
\hline & $\begin{array}{l}\text { 7. Adamya Standard Operatinal } \\
\text { Procedure (SOP) }\end{array}$ \\
\hline
\end{tabular}

\begin{tabular}{|c|c|}
\hline Stakeholder & Requirement (Kebutuhan) \\
\hline \multirow[t]{5}{*}{ Supplier } & 1. Pola order yang teratur \\
\hline & 2. Tingkat Kepuasan supplier \\
\hline & $\begin{array}{l}\text { 3. Kerja sama yang baik dan } \\
\text { sesuai kontrak }\end{array}$ \\
\hline & $\begin{array}{l}\text { 4. Komunikasi yang baik antar } \\
\text { kedua belah pihak }\end{array}$ \\
\hline & 5. Pembayaran tepat waktu \\
\hline \multirow[t]{5}{*}{ Pimpinan } & $\begin{array}{l}\text { 1. Perusahaan bergerak sesuai } \\
\text { sistem dan standar ISO }\end{array}$ \\
\hline & $\begin{array}{l}\text { 2. Adanya kesadaran para } \\
\text { pekkerja untuk menjaga } \\
\text { kestabilan dan kualitas dalam } \\
\text { sistem produksi }\end{array}$ \\
\hline & $\begin{array}{l}\text { 3. Perusahaan dappat bersaing } \\
\text { dengan sehat }\end{array}$ \\
\hline & $\begin{array}{l}\text { 4. Perencanaan produksi dan } \\
\text { target yang jelas }\end{array}$ \\
\hline & $\begin{array}{l}\text { 5. Adanya standarisasi proses } \\
\text { produksi dan kualitas }\end{array}$ \\
\hline
\end{tabular}

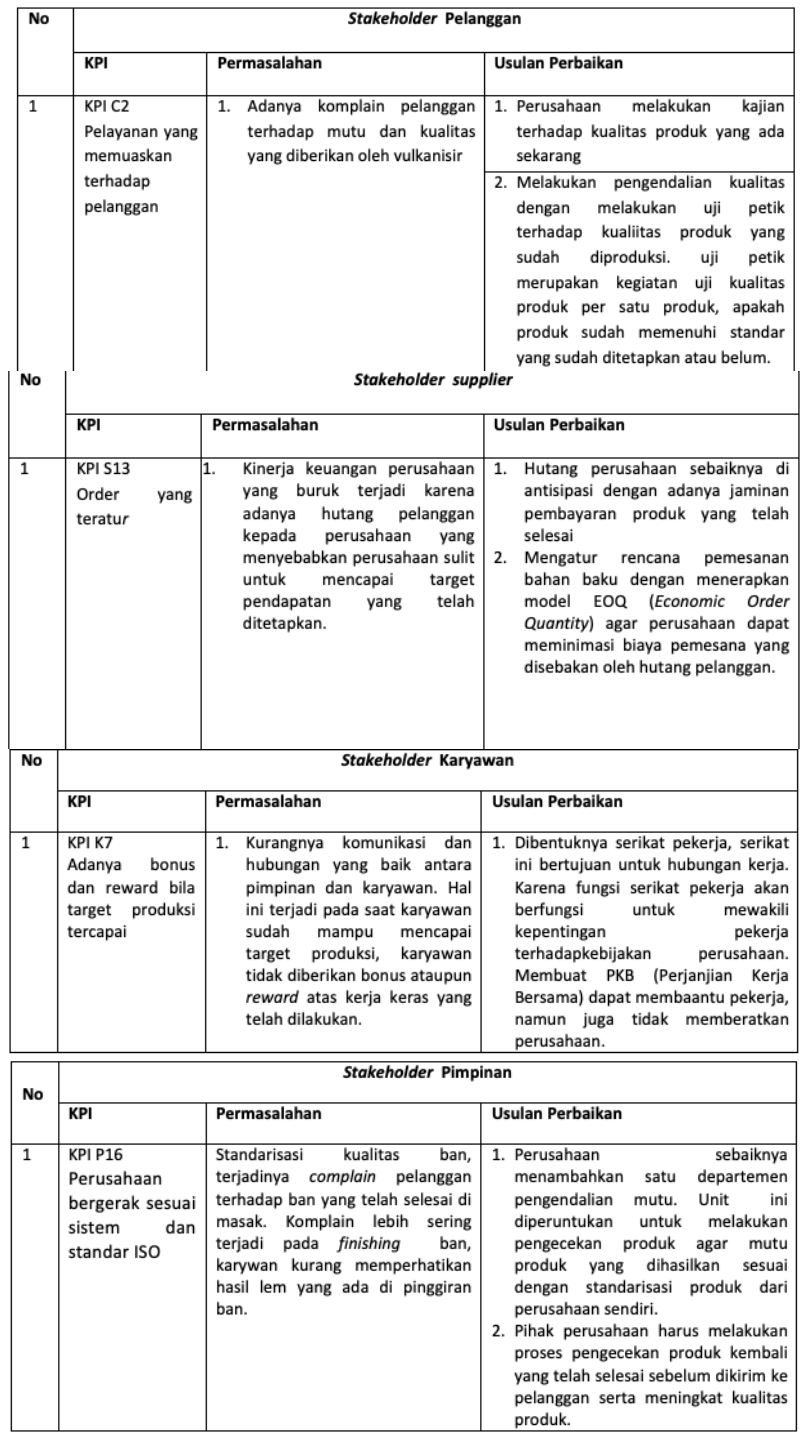

\section{Kesimpulan}

Berdasarkan hasil perhitungan bobot key performance indicators (KPI), didapatkan $4 \mathrm{KPI}$ yang memiliki bobot tertinggi dari setiap stakeholder sehingga perlu diberikan usulan perbaikan. Adapun indikator prioritas perusahaan serta usulan perbaikan yang diberikan adalah sebagai berikut:

1. Usulan perbaikan untuk KPI Pelayanan yang memuaskan terhadap pelanggan pada subkriteria pelanggan adalah perusahaan melakukan kajian terhadap kualitas produk yang ada sekarang dan melakukan pengendalian kualitas dengan melukan uji petik terhadap kualiitas produk yang sudah diproduksi. Uji petik merupakan kegiatan uji kualitas produk per satu produk, apakah produk sudah memenuhi standar yang sudah ditetapkan atau belum.

2. Usulan perbaikan untuk KPI Order yang teratur pada sub kriteria Supplier adalah Hutang perusahaan sebaiknya di antisipasi dengan adanya jaminan pembayaran produk yang telah selesai. Mengatur rencana pemesanan bahan baku dengan 
menerapkan model EOQ (Economic Order Quantity) agar perusahaan dapat meminimasi biaya pemesanan yang disebakan oleh hutang pelanggan

3. Usulan perbaikan untuk KPI adanya bonus dan reward bila target produksi tercapai pada sub kriteria karyawan adalah Dibentuknya serikat pekerja, serikat ini bertujuan untuk hubungan kerja. Karena fungsi serikat pekerja akan berfungsi untuk mewakili kepentingan pekerja terhadapkebijakan perusahaan. Membuat PKB (Perjanjian Kerja Bersama) dapat membaantu pekerja, namun juga tidak memberatkan perusahaan.

4. Usulan perbaikan untuk KPI Perusahaan bergerak sesuai sistem dan standar ISO pada sub kriteria pimpinan adalah Pimpinan Perusahaan sebaiknya menambahkan satu departemen pengendalian mutu. Unit ini diperuntukan untuk melakukan pengecekan produk agar mutu produk yang dihasilkan sesuai dengan standarisasi produk dari perusahaan sendiri. Pihak perusahaan harus melakukan proses pengecekan produk kembali yang telah selesai sebelum dikirim ke pelanggan serta meningkat kualitas produk.

\section{Daftar Pustaka}

[1] Papilo, Petir., “Pengukuran Kinerja Organisasi Dengan Penerapan Metode IPMS Yang Terintegrasi Dengan Metode Smart System (Studi Kasus : Fakultas " $x$ ")", Jurnal Teknik Industri, UIN Suska Riau, Pekanbaru. 2012.

[2] Simbolon, Freddy., "Perbandingan Sistem Pengukuran Kinerja Perusahaan", Jurnal Manajemen, Binus University, Jakarta Barat. 2015.

[3] Susetyo, Joko., "Penerapan Sistem Pengukuran Kinerja Perusahaan dengan Metode Integrated Performance Measurement System (IPMS) pada PT X". Jurnal Teknik Industri, IST AKPRIND, Yogyakarta. 2013.

[4] Winarni, dan Cahyo Purnomo., "Pengukuran Kinerja Perusahaan dengan Mtode Integrated Performance Measurement (IPMS)". Jurnal Teknik Indstri, Dosen, Alumni Jurusan Teknik Industri, IST AKPRIND, Yogyakarta. 2012.

[5] Nur, Muhammad dan Bahrul Ulum, "Usulan Perbaikan Kinerja Menggunakan Metode Performance Prism dan Analytichal Hierarchy Process di CV Robert Jaya Sejahtera". Jurnal Teknik Industri, Volume 17, No. 02, Universitas Sebelah Maret. Surakarta, 2019. 